\title{
Application of leaf leachates for weeds control in Populus deltoides $\mathbf{L}$. nursery
}

\author{
Anita Tomar ${ }^{1}$, Dinesh Kumar ${ }^{2}$ and Satya Prakash ${ }^{2}$ \\ ${ }^{1}$ Forest Research Centre for Eco-rehabilitation, Prayagraj, Uttar Pradesh, India \\ ${ }^{2}$ Forest Research Institute, Dehradun, Uttarakhand, India \\ *Corresponding Author: anitatomar@icfre.org
}

\begin{abstract}
The experiment was designed to examine if leachates and leaf extracts of Eucalyptus hybrid, Lantana camara Parthenium hysterophorus can be used as post-emergence weedicides to serve as substitutes for manual weed control in poplar nursery. Hand weeding alone is recommended for control of weeds as leachates and leaf extracts of above species did not prove effective.
\end{abstract}

Keywords: Leachates, Leaf extracts, Weed, Poplar.

\section{INTRODUCTION}

Weeds are a serious problem for every nursery manager. Left unmanaged, they can drastically lower plant survival and plant growth. Control of weeds requires huge financial expenditure. Technically, weed is any plant growing out of place, especially one that grows faster than the plants of desired species. Weed invasion in nurseries is exacerbated by application of manures, fertilizers and irrigation. Intensive nursery management requires intensive weed management (Owston \& Abrahamson, 1984). Some control measures can be biologically or economically effective but unacceptable because of adverse environmental impacts. Need is to develop effective eco-friendly weed control measures.

In India, weeds are one of the major biological constraints that limit crop productivity. They reduce quantity and quality of agricultural productivity and compete with crops for natural and applied resources (Rao \& Nagamani 2010, 2013; Rao et al., 2015), Moreover, weeds compete with crops for the same resources: water; nutrients; light and carbon dioxide (Parker, 2003). The wider the crop rotation, the more efficient the weed control (Corsi, 2017). Bhan et al. (1999) estimated that weeds in India reduce crop yields by $31.5 \%$ (22.7\% in winter and 36.5\% in summer and kharif seasons). In other studies, besides impairing quality of produce and causing health and environmental hazards, weeds were reported to cause up to one-third of the total losses in yield (DWSR, 2013). In a survey, Indian weed scientists estimated losses due to weeds from $10 \%$ to $100 \%$. Losses of this magnitude due to weeds may occur in fruits, vegetables, plantation crops, grasslands, forestry and aquatic environments. The total economic losses will be much higher, if indirect effects of weeds on health, nutrient depletion, losses of biodiversity, grain quality, etc. are taken into consideration (Yaduraju, 2012).

Weed problem occurs in nurseries in germination beds, root trainers, polythene bags, nursery beds, along paths, water channels as well as open areas in nursery. Farm Yard Manure (FYM) is a source of weed seeds and control of weed seeds in FYM itself can considerably reduce weed incidence in nursery.

Numerous reports are available in the literature showing the deleterious effect of leachates of some commercial trees (e.g. Eucalyptus hybrid) and weeds (e.g. Lantana camara L., Parthenium hysterophorus L.) etc. on germination and growth of different species. Therefore it becomes very pertinent and interesting to use these treatments for a positive outcome in terms of control of weeds in the nursery. Using this approach would require a scientific study. Therefore, the present study was carried out to examine this possibility.

The present study envisaged to examine the feasibility of using leachates of some common forestry species for ecofriendly methods of weed control i.e. the potential of leachates of Eucalyptus hybrid, Jatropha curcas L. and Lantana camara L. in weed control was explored. Eucalyptus was selected as one of the sources of leachates since it is planted on a large scale in greater part of India and allelopathic effect of this species on other plant species are reported in the literature. Lanatana camara and Parthenium hysterophorus L. have been selected as source of leachate due to their widespread occurrence as noxious weeds in forest and non-forest areas throughout India. Populus deltoides L. was test species in which weed control was carried out due to their widespread planting in north India. 


\section{MATERIALS AND METHODS}

The study was carried out in Central Nursery of Forest Research Institute Dehradun located at $30^{\circ} 19^{\prime} \mathrm{N}$ latitude and $78^{\circ} 03^{\prime}$ E longitude. The survey of nursery was carried out in different seasons of the year and weeds were recorded. Weeds extended in their life cycle for upto one year were classed as annuals. Those extending beyond one year were classed as perennials. The seasons of sprouting or germination of the weeds was also recorded.

Leaf extracts (leachates) were collected from the Eucalyptus hybrid, Lantana camara and Parthenium hysterophorus. The concentrations $(0 \%, 5 \%, 10 \%, 15 \%, 20 \%$ and $30 \%)$ were prepared on fresh weight basis. The species used for testing the efficacy of above extracts were Populus deltoides L. The studies were carried out in nursery beds. The plants were regularly irrigated. Unless otherwise stated, the standard cultural practices in nurseries followed in this region were used. In poplar sprouting and growth data were collected. Percentage was calculated as the percentage of vegetative propagules that sprouted in the experiment. Biomass was estimated on dry weight basis after drying the specimens in hot-air oven at $70^{\circ} \mathrm{C}$ for 72 hours. Randomised block design with three replications was used in all studies. Populus deltoides was planted through cuttings at spacing of $80 \mathrm{~cm} \times 60 \mathrm{~cm}$ in the nursery beds of $48 \mathrm{~m}^{2}$ size. Leaf extracts in above concentrations were applied at rates of $11 \mathrm{~m}^{-2}$ from the time of weed emergence to the end of the experiment at ten days intervals. Dried leaves of Eucalyptus hybrid, Lantana camara and Parthenium hysterophorus were applied at rate of $0.8 \mathrm{~kg} \mathrm{~m}^{-2}$ area. Cuttings were not soaked in extracts at or before sowing/planting. Growth of the test species and biomass of weed species were studied. Hand weeding was also used in each bed as and when required. Number of hand weedings carried out was recorded in each treatment. A control in which only hand weeding was done was also maintained. The no. of plants and biomass of weed species as well test species was recorded.

\section{RESULTS AND DISCUSSION}

In nature only three species viz. Cyperus rotundus L., Cynodon dactylon (L.) Pers. and Convolvulus arvensis L. are perennial. Others species studied are all annual. The seasons of occurrence, propagules and nature of the weeds are listed below in table 1 . The first four weeds in table 1 were found to be most abundant and difficult to control.

Table 1. Weeds, their seasons of occurrence, propagules and nature.

\begin{tabular}{|c|c|c|c|c|}
\hline Weed & $\begin{array}{l}\text { Common } \\
\text { Name }\end{array}$ & $\begin{array}{l}\text { Seasons of } \\
\text { observation }\end{array}$ & $\begin{array}{l}\text { Propagation } \\
\text { method }\end{array}$ & Nature \\
\hline Ageratum conyzoides $\mathrm{L}$. & Makhua & Monsoon & Seed & Annual \\
\hline Amaranthus viridis $\mathrm{L}$. & - & $\begin{array}{l}\text { Winter and } \\
\text { monsoon }\end{array}$ & Seed & Annual \\
\hline Anagallis arvensis L. & Neel & Winter & Seed & Annual \\
\hline Chenopodium album $\mathrm{L}$. & Bathua & Winter & Seed & Annual \\
\hline Convolvulus arvensis $\mathrm{L}$. & Hiran khuri & All seasons & Seed and rhizome & Perennial \\
\hline Cynodon dactylon (L.) Pers. & Doob & All seasons & $\begin{array}{l}\text { Creeping roots } \\
\text { and seeds }\end{array}$ & Perennial \\
\hline Cyperus rotundus $\mathrm{L}$. & Motha & All seasons & Seed and tubers & Perennial \\
\hline Dactyloctenium aegyptium (L.) Willd. & Makda, Mandua & Summer & Seeds & Annual \\
\hline Digera arvensis Forssk. & Lahasua & Monsoon & Seed & Annual \\
\hline Fumaria parviflora Lam. & Pitpara & Winter & Seed & Annual \\
\hline Melilotus albus Medik. & Safed senji & Winter & Seed & Annual \\
\hline Melilotus indicus (L.) All. & Peeli senji & Winter & Seed & Annual \\
\hline Phyllanthus niruri L. & Hazar dana & Monsoon & Seed & Annual \\
\hline Senecio spp. & - & Summer & Seed & Annual \\
\hline Setaria glauca (L.) Beauv. & Banari & Monsoon & Seed & Annual \\
\hline Trifolium repens $\mathrm{L}$. & White clover & Winter & Seed & Annual \\
\hline Vicia hirsuta (L.) Gray & Ankari & Winter & Seed & Annual \\
\hline Vicia sativa $\mathrm{L}$. & Ankara & Winter & Seed & Annual \\
\hline
\end{tabular}

This experiment was designed to examine if leaf extracts of Eucalyptus hybrid, Lantana camara and Parthenium hysterophorus can be used as post-emergence weedicides to serve as substitutes for manual weed control in poplar. Table 2 shows that sprouting of Populus deltoides cuttings was not affected by the treatments. Hand weeded beds had significantly greater height and collar diameter of Populus deltoides as well as cumulative biomass of weeds. Among the beds without hand weeding, there was no definite pattern of variation in height and collar diameter of Populus deltoides but cumulative biomass of weeds decreased with greater extract concentration. Application of Eucalyptus hybrid extracts for weed control proved ineffective in comparison with hand weeding in Populus deltoides. 
Table 2. Effect of post-emergence application of leaf extract of Eucalyptus hybrid in nursery bed on Populus deltoides L. and weed biomass.

\begin{tabular}{|c|c|c|c|c|c|c|}
\hline \multirow[t]{2}{*}{ Weed control method } & \multirow{2}{*}{$\begin{array}{r}\text { Sprouting } \\
(\%)\end{array}$} & \multicolumn{2}{|c|}{ July } & \multicolumn{2}{|c|}{ October } & \multirow{2}{*}{$\begin{array}{r}\text { Cumulative } \\
\text { weed biomass } \\
\text { per bed }(\mathrm{kg})\end{array}$} \\
\hline & & $\begin{array}{r}\text { Height } \\
\text { (cm) }\end{array}$ & $\begin{array}{r}\text { Collar dia } \\
(\mathbf{m m})\end{array}$ & $\begin{array}{r}\text { Height } \\
\text { (cm) }\end{array}$ & $\begin{array}{r}\text { Collar dia } \\
(\mathrm{mm})\end{array}$ & \\
\hline Hand weeding (5 times) & 100.0 & 1.40 & 22.2 & 3.41 & 31.2 & 7.87 \\
\hline Eucalyptus extract $0 \%$ & 100.0 & 0.71 & 10.1 & 0.97 & 12.5 & 3.72 \\
\hline Eucalyptus extract $10 \%$ & 96.4 & 0.83 & 9.3 & 0.99 & 11.8 & 3.89 \\
\hline Eucalyptus extract $15 \%$ & 100 & 0.69 & 11.2 & 1.17 & 13.2 & 3.30 \\
\hline Eucalyptus extract $20 \%$ & 95.8 & 0.71 & 10.0 & 1.05 & 10.7 & 3.19 \\
\hline Eucalyptus extract $30 \%$ & 92.2 & 0.60 & 9.4 & 0.90 & 12.8 & 3.28 \\
\hline CD (5\%) & NS & 0.11 & 1.46 & 0.20 & 1.89 & $\mathbf{0 . 7 7}$ \\
\hline
\end{tabular}

In Populus deltoides, extract of Lantana camara (Table 3) and Parthenium hysterophorus (Table 4) led to a significant reduction in mean height and collar diameter of Populus deltoides plants and biomass of weeds in comparison with hand weeded plots. Effect on sprouting percentage of cuttings was not significant. Greater the concentrations of extracts used, greater was the decline in biomass of weeds. By October plants treated with extract showed absence of any possibility of reaching plantable size as they could not even attain half of the plant height (at least $3 \mathrm{~m}$ ) and collar diameter (at least $3 \mathrm{~cm}$ ) recommended for outplanting of poplar. The study suggested that application of Lantana camara and Parthenium hysterophorus extracts were not effective in controlling weeds and hand weeding was a better technique for weed control in Populus deltoides in comparison with application of extracts.

Table 3. Effect of Post-emergence application of leaf extract of Lantana camara L. in nursery bed on Populus deltoides L. and weed biomass.

\begin{tabular}{|c|c|c|c|c|c|c|}
\hline \multirow[t]{2}{*}{ Weed control method } & \multirow{2}{*}{$\begin{array}{r}\text { Sprouting } \\
(\%)\end{array}$} & \multicolumn{2}{|c|}{ July } & \multicolumn{2}{|c|}{ October } & \multirow{2}{*}{$\begin{array}{r}\text { Cumulative } \\
\text { weed biomass } \\
\text { per bed (kg) }\end{array}$} \\
\hline & & $\begin{array}{r}\text { Height } \\
(\mathrm{cm})\end{array}$ & $\begin{array}{r}\begin{array}{r}\text { Collar dia } \\
(\mathrm{mm})\end{array} \\
\end{array}$ & $\begin{array}{r}\text { Height } \\
(\mathrm{cm})\end{array}$ & $\begin{array}{r}\begin{array}{r}\text { Collar dia } \\
(\mathrm{mm})\end{array} \\
\end{array}$ & \\
\hline Hand weeding ( 5 times) & 100 & 1.52 & 20.3 & 3.50 & 34.4 & 8.16 \\
\hline Lantana extract $0 \%$ & 100 & 0.80 & 11.4 & 0.92 & 11.4 & 4.11 \\
\hline Lantana extract $10 \%$ & 97.8 & 0.83 & 10.3 & 1.05 & 13.5 & 3.76 \\
\hline Lantana extract $15 \%$ & 98.5 & 0.74 & 11.7 & 1.09 & 13.3 & 3.54 \\
\hline Lantana extract $20 \%$ & 100 & 0.68 & 9.5 & 0.96 & 14.6 & 3.69 \\
\hline Lantana extract $30 \%$ & 95.5 & 0.69 & 10.5 & 1.00 & 11.7 & 3.50 \\
\hline CD (5\%) & NS & 0.19 & 2.12 & 0.17 & 1.99 & $\mathbf{0 . 8 3}$ \\
\hline
\end{tabular}

In view of failure of leaf leachates in controlling weeds in the nursery, application of dry leaves in combination with hand weeding was also tested to compare it with leaf extracts + hand weeding for its efficacy in weed control.

Table 4. Effect of post-emergence application of leaf extract of Parthenium hysterophorus L. in nursery bed on Populus deltoides L. and weed biomass.

\begin{tabular}{rrrrrrr}
\hline Weed control method & $\begin{array}{r}\text { Sprouting } \\
(\%)\end{array}$ & \multicolumn{2}{c}{ July } & \multicolumn{2}{c}{ October } & $\begin{array}{r}\text { Cumulative } \\
\text { Height } \\
\end{array}$ \\
& & $(\mathbf{c m})$ & $\begin{array}{r}\text { Collar dia } \\
(\mathbf{m m})\end{array}$ & $\begin{array}{r}\text { Height } \\
(\mathbf{c m})\end{array}$ & $\begin{array}{r}\text { Collar dia } \\
(\mathbf{m m})\end{array}$ & $\begin{array}{r}\text { eed biomass } \\
\text { per bed (kg) }\end{array}$ \\
\hline Hand weeding (5 times) & 100 & 1.65 & 20.5 & 3.56 & 33.7 & 8.88 \\
Parthenium extract 0\% & 100 & 0.79 & 11.2 & 1.03 & 12.6 & 4.54 \\
Parthenium extract 10\% & 100 & 0.74 & 11.3 & 0.99 & 12.4 & 4.22 \\
Parthenium extract 15\% & 98.5 & 0.86 & 10.4 & 1.10 & 14.6 & 3.76 \\
Parthenium extract 20\% & 100 & 0.72 & 10.6 & 1.17 & 13.0 & 3.67 \\
Parthenium extract 30\% & 96.7 & 0.77 & 9.5 & 0.98 & 12.9 & 3.51 \\
\hline CD (5\%) & NS & $\mathbf{0 . 2 1}$ & $\mathbf{2 . 1 2}$ & $\mathbf{0 . 2 0}$ & $\mathbf{2 . 2 7}$ & $\mathbf{0 . 8 5}$ \\
\hline
\end{tabular}

Table 5. Effect of leachates and dry leaves of Eucalytpus hybrid, Lantana camara L. and Parthenium hysterophorus L. on weed frequency and biomass $\left(\mathrm{m}^{-2}\right)$ in nursery bed of Populus deltoides $\mathrm{L}$.

\begin{tabular}{|c|c|c|c|c|c|c|c|c|}
\hline \multirow[t]{2}{*}{ Treatment } & \multicolumn{2}{|c|}{$\begin{array}{c}\text { Cyperus rotundus } \\
\text { L. }\end{array}$} & \multicolumn{2}{|c|}{$\begin{array}{c}\text { Dactyloctenium } \\
\text { aegyptium }(\mathbf{L} .) \text { Willd. }\end{array}$} & \multicolumn{2}{|c|}{$\begin{array}{c}\text { Amaranthus viridis } \\
\text { L. }\end{array}$} & \multicolumn{2}{|c|}{ Others } \\
\hline & $\begin{array}{l}\text { No. of } \\
\text { plants }\end{array}$ & $\begin{array}{r}\text { Weight } \\
(\mathrm{g})\end{array}$ & $\begin{array}{l}\text { No. of } \\
\text { plants }\end{array}$ & $\begin{array}{r}\text { Weight } \\
(\mathrm{g})\end{array}$ & $\begin{array}{l}\text { No. of } \\
\text { plants }\end{array}$ & $\begin{array}{r}\text { Weight } \\
(\mathrm{g})\end{array}$ & $\begin{array}{l}\text { No. of } \\
\text { plants }\end{array}$ & $\begin{array}{r}\text { Weight } \\
(\mathrm{g}) \\
\end{array}$ \\
\hline Control (+ hand weeding) & 22.1 & 48.0 & 32.3 & 53.0 & 12.0 & 62.4 & 61.9 & 91.1 \\
\hline Dry leaves Eucalyptus + hand weeding & 21.3 & 45.2 & 30.8 & 51.2 & 10.9 & 59.1 & 58.3 & 86.7 \\
\hline Dry leaves Lantana + hand weeding & 23.5 & 49.8 & 33.1 & 49.7 & 13.7 & 59.7 & 56.0 & 95.7 \\
\hline Dry leaves Parthenium + hand weeding & 25.7 & 50.7 & 30.6 & 55.9 & 14.0 & 60.8 & 55.7 & 93.1 \\
\hline Leachate Eucalyptus + hand weeding & 20.8 & 46.6 & 29.8 & 53.8 & 11.8 & 63.8 & 58.5 & 94.8 \\
\hline Leachate Lantana + hand weeding & 23.3 & 49.4 & 32.4 & 55.4 & 13.1 & 65.1 & 58.4 & 89.9 \\
\hline Leachate Parthenium + hand weeding & 22.2 & 45.9 & 35.0 & 52.1 & 14.2 & 64.6 & 60.4 & 90.6 \\
\hline CD (5\%) & NS & NS & NS & NS & NS & NS & NS & NS \\
\hline
\end{tabular}


However, in case of Populus deltoides, it was observed that there was no significant effect of application of the various treatments. Application of dry leaves of Eucalyptus hybrid or Lantana camara or Parthenium hysterophorus supplemented with manual weeding, application of leaf extracts of these species supplemented with hand weeding as well as manual weeding alone - all these treatments were on a par with one another from standpoint of weed growth (Table 5) as well as growth of Populus deltoides (Table 6). Application of dry leaves or leachates would therefore only increase the cost of weed control. Hence hand weeding alone is recommended for control of weeds in Populus deltoides.

Table 6. Effect of leachates and dry leaves of Eucalytpus hybrid, Lantana camara L. and Parthenium hysterophorus L. on growth and survival of Populus deltoides L. in nursery bed.

\begin{tabular}{|c|c|c|c|}
\hline Treatment & Height (m) & $\begin{array}{r}\text { Collar } \\
\text { diameter }(\mathrm{cm})\end{array}$ & Survival \\
\hline Control (+ hand weeding) & 5.19 & 5.32 & 99.7 \\
\hline Dry leaves Eucalyptus + hand weeding & 5.10 & 5.39 & 99.3 \\
\hline Dry leaves Lantana + hand weeding & 5.28 & 5.42 & 100 \\
\hline Dry leaves Parthenium+ hand weeding & 5.26 & 5.55 & 100 \\
\hline Leachate Eucalyptus + hand weeding & 5.11 & 5.40 & 99.0 \\
\hline Leachate Lantana + hand weeding & 5.21 & 5.28 & 99.7 \\
\hline Leachate Parthenium + hand weeding & 5.17 & 5.33 & 99.3 \\
\hline CD (5\%) & NS & NS & NS \\
\hline
\end{tabular}

\section{CONCLUSION}

Spraying of the leaf extracts and leachates on beds of Populus deltoides proved ineffective in controlling weeds. Manual weeding gave better results than application of leaf extracts and leachates. In sprayed beds sprouting of Populus deltoides cuttings were not affected but plant size was greatly reduced due to weed competition.

\section{REFERENCES}

Bhan V.M., Kumar S. \& Raghuwanshi M.S. (1999). Weed Management in India. Indian Journal of Plant Protection, 17: 71-202.

Corsi S. (2017). Conservation Agriculture Training Guide for Extension Agents and Farmers in Eastern Europe and Central Asia. Food and Agriculture Organization of the United Nations: Rome, Italy, 158 p.

DWSR (2013). Vision 2050. Directorate of Weed Science Research, Jabalpur, India.

Owston P.W. \& Abrahamson L.P. (1984). In: Duryea M.L. \& Thomas D. Landis (Eds.) Forest Nursery Manual: Production of Barerot seedlings. Martinus Nijhoff / Dr W. Junk Publ. The Hague: 193-202.

Parker R. (2003). Water Conservation, Weed Control Go Hand in Hand. Drought Advisory, Washington state university cooperation Extension and the U.S department of Agriculture (EM4856). Retrieved from: http://cru.cahe.wsu.edu/CEPublications/em4856 lem4856.pdf

Rao A.N. \& Nagamani A. (2010). Integrated Weed Management in India-Revisited. Indian Journal of Weed Science, 42: 1-10.

Rao A.N. \& Nagamani A. (2013). Eco-efficient weed management approaches for rice in tropical Asia. In: Proceedings of $4^{\text {th }}$ Tropical Weed Science Conference: Weed Management and Utilization in the Tropics held during 23-25 January, 2013. The Empress Hotel, Chiang Mai, Thailand, pp. 78-87.

Rao A.N., Wani S.P., Ramesha M. \& Ladha J.K. (2015). Weeds and Weed Management of Rice in Karnataka State, India. Weed Technology, 29(1): 1-17.

Yaduraju N.T. (2012). Weed management perspectives for India in the changing agriculture scenario in the country. Pakistan Journal of Weed Science Research, 18(spl. issue): 703-710. 